\title{
РІВЕНЬ ЕФЕКТИВНОСТІ СТРАТЕГІЙ РОЗВИТКУ БУДІВЕЛЬНОЇ
}

\section{ГАЛУЗІ УКРАЇНИ}

Кононова О.С., канд. екон. наук, доцент,

\section{ДВНЗ «Придніпровська державна академія будівництва та apхітектури»}

Постановка проблеми. Ефективність стратегічного розвитку суб'єктів будівельної галузі України характеризує стан результативності, відповідності розробки та впровадження стратегій в даній сфері на належному етапі становлення економічної системи в країні. Достовірність та всебічність оцінки цього показника дозволяє визначити дійсну картину розвитку будівельної галузі з огляду на фактичні та планові вихідні параметри функціонування. Здійснення такої оцінки можливе за умов використання ефективної, грунтовної та надійної методики аналізу, яка б враховувала всебічні характеристики стратегічного розвитку підприємств будівельної галузі України.

Аналіз останніх досліджень i публікацій. Питання, пов'язані 3 розвитком будівельної галузі, знайшли відображення в роботах Токаревої О., Крикуна К., Рогожина П., Гойко А. та ін. Проблематиці функціонування та розвитку підприємств будівельної галузі присвячено роботи Асаула А., Божанової В., Верхоглядової Н., Вечерова В., Глухової С., Дружиніна А., Залуніна В., Іванілова О., Калугіна Ю., Конащука В., Млодецького В., Опєкунова В., Орловської Ю., Полякова І., Радкевича А., Ступнікер Г., Торкатюка В., Тяна Р., Цуцаєва О., Шутенка Л. та ін.

Невирішені складові загальної проблеми. Нині значна увага вітчизняними науковцями приділяється аналізу сучасної ситуації та інвестиційної привабливості будівельної галузі України, стану та перспективам регіонального розвитку капітального будівництва. Однак наявність проблем та кризової ситуації в галузі є достатнім обгрунтуванням необхідності подальших розробок та опрацювання проблеми розвитку будівельної галузі, пошуку оптимальних шляхів впровадження стратегій розвитку в будівельні підприємства України.

Формулювання цілей статті. Метою дослідження $\epsilon$ визначення загального впливу факторів дії, відповідних для будівельної галузі, та впливу додаткових внутрішніх факторів суб'єктів будівельної галузі країни впродовж аналізованого періоду.

Виклад основного матеріалу дослідження. Методика оцінки ефективності стратегій розвитку підприємств будівельної галузі України враховує всебічний та широкий діапазон оціночних показників (обсяги доходу (виручки) від реалізації будівельної продукції, обсяги виробництва будівельної продукції, частку ринку згідно планових та звітних параметрів реалізації стратегії розвитку). Визначення рівня ефективності впровадження планової (задекларованої) стратегії розвитку досліджуваними підприємствами будівельної галузі дасть змогу сформулювати картину історіографії змін 
вказаного показника в країні в рамках досліджуваного періоду. Відповідно, зміни зазначеного показника дадуть змогу оцінити стан трансформацій стратегічного розвитку будівельної галузі в країні, встановити найбільш вагомий вплив факторів на рівень ефективності впровадження стратегій. При цьому, у якості факторів, що впливають на стан вказаного показника, будуть розглядатись ті, які обрано в складі визначальних в процесі оцінки їх впливу (зокрема, зовнішні, внутрішні та міжнародні). Характер їх впливу буде співставлено 3 рівнем ефективності впровадження стратегій розвитку на досліджуваних (найбільших) підприємствах будівельної галузі країни. Така залежність дозволить визначити, які фактори $\epsilon$ основними і потребують найбільшої уваги в процесі стратегічного планування та реалізації стратегій розвитку. Відповідно до авторської методики наведено формулу 1 , в якій визначено порядок розрахунку рівня відповідності стратегії розвитку реалізованому потенціалу підприємства (Creal).

$$
\begin{aligned}
& \text { Creal } \rightarrow \text { якщо (Ctr (Crep1, Crep2, Crep3....) - Sdi (Cp11, Cp12, Cpl3....)) / (Sdi } \\
& (\mathrm{Cp} 11, \mathrm{Cp} 12, \mathrm{Cp} 13 . . .)) * 100(\%) \sim \%(\text { Chopta1, Chopta1, Chopta1), } \\
& \text { (формула 1) [авторська розробка] }
\end{aligned}
$$

де Sdi - задекларована стратегія розвитку;

$\mathrm{Cpl}$ - плановий параметр результативності відповідно до задекларованої стратегії розвитку (обсяг доходу (виручки) від реалізації, обсяг виробництва будівельної продукції, частка ринку тощо);

Sdi (Cpl1, Cpl2, Cpl3....) - основні планові параметри результативності відповідно до задекларованої стратегії розвитку;

Crep - звітний параметр результативності цільових показників, використаних в задекларованій стратегії розвитку (обсяг доходу (виручки) від реалізації, обсяг виробництва будівельної продукції, частика ринку тощо);

Ctr (Crep1, Crep2, Crep3....) - основні звітні параметри результативності за показниками, використаними у якості основних оціночних в задекларованій стратегії розвитку;

$\%($ Chopta1, Chopta1, Chopta1) - зростання можливостей за кожним 3 стратегічних параметрів розвитку, \%. Загальний рівень (сума \% за всіма показниками) показника \%(Chopta1, Chopta1, Chopta1) повинен дорівнювати відсотку зростання стратегічних планових показників порівняно із звітними. В рамках методики визначається, що можливість:

- зростання обсягів доходу (виручки) від реалізації будівельної продукції на \% (певний відсоток) обгрунтовується певними плановими параметрами (ціновими, ринковими);

- збільшення обсягів виробництва будівельної продукції - відсотком (\%) оптимізації виробничого обладнання, робочої сили зазначеного будівельного підприємства тощо;

- зріст частки ринку - відсотком (\%) зростання обсягу збуту або виробництва будівельної продукції даної підприємницької структури на рівні галузі тощо. 
Згідно із умовами авторської методики, порядок оцінки ефективності впровадження планової (задекларованої) стратегії розвитку досліджуваним підприємством будівельної галузі (Effst) представлено в формулі 2.

Effst $=(\mathrm{A}(\mathrm{Crep} 1, \mathrm{Crep} 2, \mathrm{Crep} 3 \ldots .)-.(\mathrm{A}(\mathrm{Cp} 11, \mathrm{Cp} 12, \mathrm{Cpl} 3 \ldots .).) / \mathrm{A}(\mathrm{Cp} 11, \mathrm{Cp} 12$, Cp13....) $)+($ B(FErep1, FEep2, FErep3.... $)-($ B(FEp11, FEl2, FE13 ....) / B(FEp11, FEl2, FEl3....) $)+($ Cinvrep - Cinvpl) $/$ CInvpl) $)+1$, (формула 2) [авторська розробка]

$\mathrm{A}(\mathrm{Cp} 11, \mathrm{Cp} 12, \mathrm{Cp} 13 \ldots .$.$) - основні стратегічні планові показники, які$ ідентифікують напрямок обраної стратегії розвитку;

A(Crep1, Crep2, Crep3....) - основні стратегічні звітні показники, які ідентифікують напрямок стратегії розвитку;

B(FEpl1, FEl2, FEl3....) - основні стратегічні фінансово-економічні планові показники, визначені на плановому рівні підприємства будівельної галузі;

B(FErep1, FEep2, FErep3....) - основні стратегічні звітні фінансовоекономічні планові показники реалізовані на рівні підприємства будівельної галузі;

CInvpl - планова ефективність інвестицій (та або оновлення основних засобів (обладнання), нематеріальних активів (технологій) за балансовою вартістю)), передбачених стратегією розвитку підприємства, \%. Вказаний показник визначається на рівні стратегічного планування. Також розглядається склад та структура інвестицій (та або оновлення основних засобів (обладнання), нематеріальних активів (технологій) за балансовою вартістю)), націлених на впровадження стратегії розвитку будівельного підприємства, зокрема, оцінюються: їх обсяги, динаміка за визначений період; структура за джерелами фінансування (власні та залучені фінансові кошти), динаміка щодо такої структури в часовому вимірі тощо;

Cinvrep - звітна ефективність інвестицій (та або оновлення основних засобів (обладнання), нематеріальних активів (технологій) за балансовою вартістю)) в рамках впровадження стратегії розвитку підприємства, \%. У разі, якщо було отримано рівень ефективності нижче прогнозного, визначеного на плановому рівні, здійснюється висновок щодо неефективності інвестицій (оновлення основних засобів та нематеріальних активів), неефективного управління інвестиційним за цим напрямком на стратегічному рівні досліджуваного будівельного підприємства. Якщо інвестування (вкладення у вказані активи (основні засоби та нематеріальні активи)) виявилось збитковим за результатами впровадження стратегії розвитку, констатується неефективність інвестиційного управління, загрозливі явища за даним напрямком на вказаному підприємстві галузі.

Якщо Effst > 1 - здійснюється висновок щодо забезпечення позапланової ефективності впровадження стратегії розвитку та дії додаткових факторів впливу. Зокрема, оцінюється ефект впливу впровадження інновацій (BInnrep - 
Binnpl) / BInnrep)\%, ефект оперативного коригування та реагування в процесі стратегічного управління (Csyneff\%).

де BInnpl - інновації у кількісному або вартісному вимірі, визначені на рівні стратегічного планування;

BInnrep - впровадження інновацій у кількісному або вартісному вимірі відповідно до результатів стратегічного управління на досліджуваному будівельному підприємстві;

Csyneff\% - синергетичний ефект від оперативного коригування та реагування в процесі стратегічного управління, інновацій. В складі напрямків оперативного коригування та реагування в процесі стратегічного управління визначаються: зміна витратомісткості; інші варіанти трансформацій.

Якщо Effst $=0$ або $\leq 1-$ визначається досягнення стратегічних планових показників на рівні будівельного підприємства.

Якщо Effst $<0$ - встановлюється факт відсутності досягнення стратегічних планових показників на рівні досліджуваного будівельного підприємства. Таким чином, проведемо оцінку ефективності впровадження планової (задекларованої) стратегії розвитку досліджуваних підприємств будівельної галузі України (ДП АТ «БК «Укрбуд», ПрАТ «ХК «Київміськбуд», ПрАТ «Домобудівний комбінат № 4» (структурний елемент Корпорації «ДБКЖИТЛОБУД»), ПрАТ «Завод залізобетонних конструкцій № 1», ТОВ «Астроінвест-Енерджі») впродовж 2015-2017 pp. Вихідні дані для проведення дослідження - дані фінансової та корпоративної звітності вказаних суб' єктів господарювання за цей період. На першому етапі проведемо розрахунок та оцінку ефективності впровадження планової (задекларованої) стратегії розвитку досліджуваних підприємств будівельної галузі України за 2015-2017 pр. В табл. 1 наведено визначення рівня ефективності впровадження планової (задекларованої) стратегії розвитку досліджуваним підприємством будівельної галузі (Effst) ДП АТ «БК «Укрбуд» (Creal) за 2015-2017 pp.

Таблицяя 1

Рівень ефективності впровадження планової (задекларованої) стратегії розвитку досліджуваним підприсмством будівельної галузі (Effst) ДП АТ «БК «Укрбуд» (Creal) за 2015-2017 pp.

\begin{tabular}{|c|c|c|c|c|c|c|}
\hline \multirow[b]{2}{*}{$\begin{array}{l}\text { № } \\
\text { 3/П }\end{array}$} & \multirow[b]{2}{*}{$\begin{array}{l}\text { Найменування оціночного } \\
\text { показника стратегії розвитку }\end{array}$} & \multirow[b]{2}{*}{2015 p. } & \multirow[b]{2}{*}{2016 p. } & \multirow[b]{2}{*}{2017 p. } & \multicolumn{2}{|c|}{ Зміна( +/-) } \\
\hline & & & & & $\begin{array}{l}\text { в } 2016 \mathrm{p} . \\
\text { порівняно } \\
\text { з } 2015 \text { р. }\end{array}$ & $\begin{array}{l}\text { в } 2017 \mathrm{p} . \\
\text { порівняно } \\
\text { з } 2016 \mathrm{p} .\end{array}$ \\
\hline 1 & 2 & 3 & 4 & 5 & 6 & 7 \\
\hline 1 & $\begin{array}{l}\text { Звітні дані (2015-2017 pp. - pез } \\
\text { стратегії із орієнтиром на скороче }\end{array}$ & $\begin{array}{l}\text { ьтат вп] } \\
\text { всіх по }\end{array}$ & $\begin{array}{l}\text { Ідження } \\
\text { Іиків - на }\end{array}$ & $\begin{array}{l}\text { атегії p } \\
\text { ямок A) }\end{array}$ & Ітку - ста & ілізаційної \\
\hline 1.1 & $\begin{array}{l}\text { Обсяг доходу (виручки) від } \\
\text { реалізації будівельної продукції } \\
\text { (Sdi (Cpl1), тис. грн. }\end{array}$ & 188140,8 & 364861,2 & 534253,2 & 176720,4 & 169392 \\
\hline
\end{tabular}


Продовження таблиці 1

\begin{tabular}{|c|c|c|c|c|c|c|}
\hline 1 & 2 & 3 & 4 & 5 & 6 & 7 \\
\hline 1.2 & $\begin{array}{l}\text { Обсяг виробництва будівельної } \\
\text { продукції (Sdi (Cp12), тис. грн. }\end{array}$ & 138625 & 270930 & 346885 & 132305 & 75955 \\
\hline 1.3 & $\begin{array}{|lrr|}\text { Обсяг чистого прибутку } & \text { (Sdi } \\
(\mathrm{Cp} 13), \text { тис. грн. } & & \\
\end{array}$ & 3178 & 6048 & 6795 & 2870 & 747 \\
\hline 1.4 & $\begin{array}{l}\text { Частка ринку (відношення обсягу } \\
\text { виробництва підприємства до } \\
\text { обсягу виробництва в галузі) (Sdi } \\
\text { (Cpl4), тис. грн. }\end{array}$ & 0,241 & 0,367 & 0,328 & 0,126 & $-0,039$ \\
\hline 1.5 & \begin{tabular}{|lrr} 
Звітна & ефективність & інвестицій \\
(та/або & оновлення & основних \\
засобів & (обладнання), \\
нематеріальних & активів \\
(технологій) & за & балансовою \\
вартістю)) & в & рамках \\
впровадження & стратегії розвитку \\
підприємства, & (Cinvrep), \% \\
\end{tabular} & 0 & 0 & 0 & 0 & 0 \\
\hline 2 & $\begin{array}{l}\text { Планові стратегічні дані }(2015-20 \\
\text { розвитку - стабілізаційної стратегі } \\
\text { А) }\end{array}$ & $\begin{array}{ll}17 & \text { pp. }- \text { п } \\
\text { ï iз оріснти] }\end{array}$ & $\begin{array}{l}\text { ланування } \\
\text { ом на ско }\end{array}$ & $\begin{array}{l}\text { результату } \\
\text { очення всіх }\end{array}$ & $\begin{array}{l}\text { провадже } \\
\text { токазникі }\end{array}$ & $\begin{array}{r}\text { стратегії } \\
\text { напрямок }\end{array}$ \\
\hline 2.1 & \begin{tabular}{|l|l|} 
Обсяг доходу (виручки) від \\
реалізації будівельної продукції \\
(Sdi (Cpl1), тис. грн.
\end{tabular} & 142374,60 & 135255,9 & 128493,08 & $-7118,7$ & $-6762,79$ \\
\hline 2.2 & $\begin{array}{l}\text { Обсяг виробництва будівельної } \\
\text { продукції (Sdi (Cp12), тис. грн. }\end{array}$ & 101107,55 & 96052,17 & 91249,56 & $-5055,38$ & $-4802,61$ \\
\hline 2.3 & $\begin{array}{l}\text { Обсяг чистого } \\
\text { (Cpl3), тис. грн. }\end{array}$ & 2908,90 & 2763,46 & 2625,28 & $-145,44$ & $-138,18$ \\
\hline 2.4 & $\begin{array}{l}\text { Частка ринку (відношення обсягу } \\
\text { виробництва підприємства до } \\
\text { обсягу виробництва в галузі) (Sdi } \\
\text { (Cpl4), тис. грн. }\end{array}$ & 0,20 & 0,19 & 0,18 & $-0,01$ & $-0,01$ \\
\hline 2.5 & \begin{tabular}{|lrr} 
Планова ефективність & інвестицій \\
(та/або оновлення & основних \\
засобів & (обладнання), \\
нематеріальних & активів \\
(технологій) & за & балансовою \\
вартістю)), & передбачених \\
стратегією & розвитку \\
підприємства, (CInvpl), \% \\
\end{tabular} & 0 & 0 & 0 & 0 & 0 \\
\hline 3 & $\begin{array}{|lr|}\text { Ефективність } & \text { впровадження } \\
\text { планової } & \text { (задекларованої) } \\
\text { стратегії розвитку досліджуваним } & \\
\text { підприємством будівельної галузі } \\
\text { (Effst), в т.ч. за рахунок: }\end{array}$ & 2,003 & 6,662 & 9,386 & 4,659 & 2,724 \\
\hline 3.1 & $\begin{array}{l}\text { ефекту впливу впровадження } \\
\text { iнновацій (BInnrep - Binnpl) / } \\
\text { BInnrep), \% }\end{array}$ & 100 & 100 & 100 & 0 & 0 \\
\hline
\end{tabular}

Джерело: складено автором за матеріалами [1; 2; 3]

За результатами проведених розрахунків (табл. 1) можемо констатувати наступне, зокрема:

1) впродовж досліджуваного періоду вказане підприємство галузі не здійснювало інвестицій в розвиток, оновлення основних засобів (обладнання), нематеріальних активів (технологій). Але була здійснена диверсифікація 
використання існуючого обладнання, технологій, проведено ремонт фактичного обладнання, які дали змогу впровадити інноваційну локальну стратегію (впровадження в квартирах, які будує компанія, системи «Розумний дім», що дозволяє забезпечувати економне використання енергетичних ресурсів, високий комфорт та безпечне життя (керування житлом в електронній формі із використанням гаджетів, зокрема, смартфонів));

2) рівень ефективності впровадження планової (задекларованої) стратегії розвитку досліджуваним підприємством будівельної галузі (Effst) впродовж трьох років зростав і в 2017 р. склав 9,386. Це високе значення, яке свідчить про забезпечення позапланової ефективності впровадження стратегії розвитку та дії додаткових факторів впливу, серед яких, зокрема, ефект впливу впровадження інновацій (BInnrep - Binnpl) / BInnrep), \%. Відповідно, можна відмітити, що впровадження вказаної інновації (впровадження в квартирах, які будує компанія, системи «Розумний дім») забезпечило покращення фінансовоекономічних та ринкових показників. В табл. 2 представлено визначення рівня ефективності впровадження планової (задекларованої) стратегії розвитку досліджуваним підприємством будівельної галузі (Effst) ПрАТ «ХК «Київміськбуд» (Creal) за 2015-2017 pp.

Таблиия 2

Рівень ефективності впровадження планової (задекларованої) стратегії розвитку досліджуваним підприємством будівельної галузі (Effst) ПрАТ «ХК «Київміськбуд» (Creal) за 2015-2017 pp.

\begin{tabular}{|c|c|c|c|c|c|c|}
\hline \multirow[b]{2}{*}{$\begin{array}{l}\text { № } \\
\text { 3/ח }\end{array}$} & \multirow[b]{2}{*}{$\begin{array}{c}\text { Найменування оціночного } \\
\text { показника стратегії розвитку }\end{array}$} & \multirow[b]{2}{*}{2015 p. } & \multirow[b]{2}{*}{2016 p. } & \multirow[b]{2}{*}{2017 p. } & \multicolumn{2}{|c|}{ Зміна (+/-) } \\
\hline & & & & & $\begin{array}{c}\text { в } 2016 \text { р. } \\
\text { порівняно } \\
2015 \text { p. }\end{array}$ & $\begin{array}{c}\text { в } 2017 \mathrm{p} . \\
\text { порівняно } \\
\text { з } 2016 \mathrm{p} .\end{array}$ \\
\hline 1 & 2 & 3 & 4 & 5 & 6 & 7 \\
\hline 1 & Звітні дані (2015-2017 pp. - резу & ьтат впрова & ження стра & егій розвитку & & \\
\hline \multirow[t]{3}{*}{1.1} & $\begin{array}{l}\text { Обсяг доходу (виручки) від } \\
\text { реалізації будівельної } \\
\text { продукції (Ctr (Crep1), тис. } \\
\text { грн., в т.ч.: }\end{array}$ & 2511182,4 & 3560553,6 & 3750969,6 & 1049371,2 & 190416 \\
\hline & $\begin{array}{l}\text { Напрямок А - через } \\
\text { впровадження стратегії } \\
\text { концентрованого росту (збут } \\
\text { висококонкурентного } \\
\text { портфелю об'єктів нерухомості } \\
\text { в рамках первинного ринку } \\
\text { нерухомого житлового майна), } \\
\text { тис. грн. }\end{array}$ & 784744,50 & $\begin{array}{c}1659574,0 \\
3\end{array}$ & 1402112,44 & 874829,53 & $-257461,59$ \\
\hline & $\begin{array}{l}\text { Напрямок В - через } \\
\text { впровадження стратегії } \\
\text { інтегрованого росту (освоєння } \\
\text { нових сегментів ринку } \\
\text { просування та збуту } \\
\text { будівельної продукції за } \\
\text { рахунок охоплення споживачів } \\
\text { з низьким рівнем доходів), тис. } \\
\text { грн. }\end{array}$ & $\begin{array}{c}1130032,0 \\
8\end{array}$ & $\begin{array}{c}1207027,6 \\
7\end{array}$ & 1542398,70 & 76995,59 & 335371,03 \\
\hline
\end{tabular}


Продовження таблиці 2

\begin{tabular}{|c|c|c|c|c|c|c|}
\hline 1 & 2 & 3 & 4 & 5 & 6 & 7 \\
\hline & $\begin{array}{l}\text { Напрямок С - через } \\
\text { впровадження інноваційної } \\
\text { локальної стратегії, тис. грн. }\end{array}$ & 596405,82 & 693951,9 & 806458,46 & 97546,08 & 112506,57 \\
\hline \multirow[t]{4}{*}{1.2} & $\begin{array}{l}\text { Обсяг виробництва будівельної } \\
\text { продукції (Ctr (Crep2), тис. } \\
\text { грн., в т.ч.: }\end{array}$ & 1866537 & 2684452 & 2857359 & 817915,00 & 172907 \\
\hline & $\begin{array}{l}\text { Напрямок А - через } \\
\text { впровадження стратегії } \\
\text { концентрованого росту (збут } \\
\text { висококонкурентного } \\
\text { портфелю об’єктів нерухомості } \\
\text { в рамках первинного ринку } \\
\text { нерухомого житлового майна), } \\
\text { тис. грн. }\end{array}$ & 583292,81 & $\begin{array}{l}1251223,0 \\
8\end{array}$ & 1068080,79 & 667930,26 & $-183142,28$ \\
\hline & $\begin{array}{l}\text { Напрямок В - через } \\
\text { впровадження стратегії } \\
\text { інтегрованого росту (освоєння } \\
\text { нових сегментів ринку } \\
\text { просування та збуту } \\
\text { будівельної продукції за } \\
\text { рахунок охоплення споживачів } \\
\text { з низьким рівнем доходів), тис. } \\
\text { грн. }\end{array}$ & 839941,65 & 910029,23 & 1174946,02 & 70087,58 & 264916,79 \\
\hline & $\begin{array}{l}\text { Напрямок С - через } \\
\text { впровадження інноваційної } \\
\text { локальної стратегії, тис. грн. }\end{array}$ & 443302,54 & 523199,69 & 614332,19 & 79897,16 & 91132,5 \\
\hline \multirow[t]{4}{*}{1.3} & $\begin{array}{l}\text { Обсяг чистого прибутку (Ctr } \\
\text { (Crep3), тис. грн., в т.ч.: }\end{array}$ & 90922 & 98803 & 71231 & 7881,00 & -27572 \\
\hline & $\begin{array}{l}\text { Напрямок А - через } \\
\text { впровадження стратегії } \\
\text { концентрованого росту (збут } \\
\text { висококонкурентного } \\
\text { портфелю об’єктів нерухомості } \\
\text { в рамках первинного ринку } \\
\text { нерухомого житлового майна), } \\
\text { тис. грн. }\end{array}$ & 28413,13 & 46052,08 & 26626,15 & 17638,95 & $-19425,93$ \\
\hline & $\begin{array}{l}\text { Напрямок В - через } \\
\text { впровадження стратегії } \\
\text { інтегрованого росту (освоєння } \\
\text { нових сегментів ринку } \\
\text { просування та збуту } \\
\text { будівельної продукції за } \\
\text { рахунок охоплення споживачів } \\
\text { з низьким рівнем доходів), тис. } \\
\text { грн. }\end{array}$ & 40914,9 & 33494,22 & 29290,19 & $-7420,68$ & $-4204,03$ \\
\hline & $\begin{array}{l}\text { Напрямок С-через } \\
\text { впровадження інноваційної } \\
\text { локальної стратегії, тис. грн. }\end{array}$ & 21593,98 & 19256,70 & 15314,67 & $-2337,27$ & $-3942,04$ \\
\hline 1.4 & $\begin{array}{l}\text { Частка ринку (відношення } \\
\text { обсягу виробництва } \\
\text { підприємства до обсягу } \\
\text { виробництва в галузі) (Ctr } \\
\text { (Crep4), \%, в т.ч.: }\end{array}$ & 3,245 & 3,641 & 2,704 & 0,40 & $-0,94$ \\
\hline
\end{tabular}


Продовження таблиці 2

\begin{tabular}{|c|c|c|c|c|c|c|}
\hline 1 & 2 & 3 & 4 & 5 & 6 & 7 \\
\hline & $\begin{array}{l}\text { Напрямок А - через } \\
\text { впровадження стратегії } \\
\text { концентрованого росту (збут } \\
\text { висококонкурентного } \\
\text { портфелю об'єктів нерухомості } \\
\text { в рамках первинного ринку } \\
\text { нерухомого житлового майна), } \\
\%\end{array}$ & 1,01 & 1,70 & 1,01 & 0,68 & $-0,69$ \\
\hline & $\begin{array}{l}\text { Напрямок В - через } \\
\text { впровадження стратегії } \\
\text { інтегрованого росту (освоєння } \\
\text { нових сегментів ринку } \\
\text { просування та збуту } \\
\text { будівельної продукції за } \\
\text { рахунок охоплення споживачів } \\
\text { з низьким рівнем доходів), \% }\end{array}$ & 1,46 & 1,23 & 1,11 & $-0,23$ & $-0,12$ \\
\hline & $\begin{array}{l}\text { Напрямок C - через } \\
\text { впровадження інноваційної } \\
\text { локальної стратегії, \% }\end{array}$ & 0,77 & 0,71 & 0,58 & $-0,06$ & $-0,13$ \\
\hline 1.5 & $\begin{array}{l}\text { Звітна ефективність інвестицій } \\
\text { (та або оновлення основних } \\
\text { засобів (обладнання), } \\
\text { нематеріальних активів } \\
\text { (технологій) за балансовою } \\
\text { вартістю)) в рамках } \\
\text { впровадження стратегії } \\
\text { розвитку підприємства, } \\
\text { (Cinvrep), \% }\end{array}$ & 0 & 0 & 0 & 0 & 0 \\
\hline 2 & \multicolumn{6}{|c|}{$\begin{array}{l}\text { Планові стратегічні дані (2015-2017 pp. } \\
\text { розвитку) }\end{array}$} \\
\hline \multirow[t]{4}{*}{2.1} & $\begin{array}{l}\text { Обсяг доходу (виручки) від } \\
\text { реалізації будівельної } \\
\text { продукції (Sdi (Cpl1), тис.грн., } \\
\text { в т.ч.: }\end{array}$ & 2880779,9 & 3560553,6 & 3750969,6 & 679773,7 & 190416 \\
\hline & $\begin{array}{l}\text { Напрямок А - через } \\
\text { впровадження стратегії } \\
\text { концентрованого росту (збут } \\
\text { висококонкурентного } \\
\text { портфелю об’єктів нерухомості } \\
\text { в рамках первинного ринку } \\
\text { нерухомого житлового майна), } \\
\text { тис. грн. }\end{array}$ & 900243,72 & $\begin{array}{l}1659574,0 \\
3\end{array}$ & 1402112,44 & 759330,31 & $-257461,6$ \\
\hline & $\begin{array}{l}\text { Напрямок В - через } \\
\text { впровадження стратегії } \\
\text { інтегрованого росту (освоєння } \\
\text { нових сегментів ринку } \\
\text { просування та збуту } \\
\text { будівельної продукції за } \\
\text { рахунок охоплення споживачів } \\
\text { з низьким рівнем доходів), тис. } \\
\text { грн. }\end{array}$ & $\begin{array}{l}1296350,9 \\
6\end{array}$ & $\begin{array}{l}1207027,6 \\
7\end{array}$ & 1542398,70 & $-89323,29$ & 335371,03 \\
\hline & $\begin{array}{l}\text { Напрямок С - через } \\
\text { впровадження інноваційної } \\
\text { локальної стратегії, тис. грн. }\end{array}$ & 684185,23 & 693951,90 & 806458,46 & 9766,67 & 112506,57 \\
\hline
\end{tabular}


Продовження таблиці 2

\begin{tabular}{|c|c|c|c|c|c|c|}
\hline 1 & 2 & 3 & 4 & 5 & 6 & 7 \\
\hline \multirow[t]{4}{*}{2.2} & $\begin{array}{l}\text { Обсяг виробництва будівельної } \\
\text { продукції (Sdi (Cpl2), в т.ч.: }\end{array}$ & $\begin{array}{c}2164757 \\
, 95\end{array}$ & 2684452 & 2857359 & 519694,05 & 172907 \\
\hline & $\begin{array}{l}\text { Напрямок А - через } \\
\text { впровадження стратегії } \\
\text { концентрованого росту (збут } \\
\text { висококонкурентного портфелю } \\
\text { об’єктів нерухомості в рамках } \\
\text { первинного ринку нерухомого } \\
\text { житлового майна), тис. грн. } \\
\end{array}$ & $\begin{array}{l}676486 \\
86\end{array}$ & $\begin{array}{c}1251223,0 \\
8\end{array}$ & 1068080,79 & 574736,22 & $-183142,28$ \\
\hline & $\begin{array}{l}\text { Напрямок В - через } \\
\text { впровадження стратегії } \\
\text { інтегрованого росту (освоєння } \\
\text { нових сегментів ринку } \\
\text { просування та збуту будівельної } \\
\text { продукції за рахунок охоплення } \\
\text { споживачів з низьким рівнем } \\
\text { доходів), тис. грн. }\end{array}$ & $\begin{array}{c}974141 \\
08\end{array}$ & 910029,23 & 1174946,02 & $-64111,85$ & 264916,79 \\
\hline & $\begin{array}{l}\text { Напрямок С-через } \\
\text { впровадження інноваційної } \\
\text { локальної стратегії, тис. грн. }\end{array}$ & $\begin{array}{c}514130 \\
01\end{array}$ & 523199,69 & 614332,19 & 9069,68 & 91132,49 \\
\hline \multirow[t]{4}{*}{2.3} & $\begin{array}{l}\text { Обсяг чистого прибутку (Sdi } \\
\text { (Cpl3), тис. грн. в т.ч.: }\end{array}$ & 79806,6 & 98803 & 71231 & 18996,4 & -27572 \\
\hline & $\begin{array}{l}\text { Напрямок А - через } \\
\text { впровадження стратегії } \\
\text { концентрованого росту (збут } \\
\text { висококонкурентного портфелю } \\
\text { об’єктів нерухомості в рамках } \\
\text { первинного ринку нерухомого } \\
\text { житлового майна), тис. грн. } \\
\end{array}$ & $\begin{array}{c}24939,5 \\
6\end{array}$ & 46052,08 & 26626,15 & 21112,52 & $-19425,93$ \\
\hline & $\begin{array}{l}\text { Напрямок В - через } \\
\text { впровадження стратегії } \\
\text { інтегрованого росту (освоєння } \\
\text { нових сегментів ринку } \\
\text { просування та збуту будівельної } \\
\text { продукції за рахунок охоплення } \\
\text { споживачів з низьким рівнем } \\
\text { доходів), тис. грн. }\end{array}$ & $\begin{array}{c}35912,9 \\
7\end{array}$ & 33494,22 & 29290,19 & $-2418,75$ & $-4204,03$ \\
\hline & $\begin{array}{l}\text { Напрямок С - через } \\
\text { впровадження інноваційної } \\
\text { локальної стратегії, тис. грн. }\end{array}$ & $\begin{array}{c}18954,0 \\
7\end{array}$ & 19256,70 & 15314,67 & 302,64 & $-3942,04$ \\
\hline \multirow[t]{2}{*}{2.4} & $\begin{array}{l}\text { Частка ринку (відношення } \\
\text { обсягу виробництва } \\
\text { підприємства до обсягу } \\
\text { виробництва в галузі) (Sdi } \\
\text { (Cp14), \%, в т.ч. }\end{array}$ & 3,245 & 3,641 & 2,704 & 0,40 & $-0,94$ \\
\hline & $\begin{array}{l}\text { Напрямок А - через } \\
\text { впровадження стратегії } \\
\text { концентрованого росту (збут } \\
\text { висококонкурентного портфелю } \\
\text { об’єктів нерухомості в рамках } \\
\text { первинного ринку нерухомого } \\
\text { житлового майна),\% }\end{array}$ & 1,01 & 1,70 & 1,01 & 0,68 & $-0,69$ \\
\hline
\end{tabular}


Продовження таблиці 2

\begin{tabular}{|c|c|c|c|c|c|c|}
\hline 1 & 2 & 3 & 4 & 5 & 6 & 7 \\
\hline & $\begin{array}{l}\text { Напрямок В - через } \\
\text { впровадження стратегії } \\
\text { інтегрованого росту (освоєння } \\
\text { нових сегментів ринку } \\
\text { просування та збуту будівельної } \\
\text { продукції за рахунок охоплення } \\
\text { споживачів з низьким рівнем } \\
\text { доходів), \% }\end{array}$ & 1,46 & 1,23 & 1,11 & $-0,23$ & $-0,12$ \\
\hline & $\begin{array}{l}\text { Напрямок С - через } \\
\text { впровадження інноваційної } \\
\text { локальної стратегії, \% }\end{array}$ & 0,77 & 0,71 & 0,58 & $-0,06$ & $-0,13$ \\
\hline 2.5 & $\begin{array}{l}\text { Планова ефективність інвестицій } \\
\text { (та або оновлення основних } \\
\text { засобів (обладнання), } \\
\text { нематеріальних активів } \\
\text { (технологій) за балансовою } \\
\text { вартістю)), передбачених } \\
\text { стратегією розвитку } \\
\text { підприємства, (CInvpl), \%. }\end{array}$ & 0 & 0 & 0 & 0 & 0 \\
\hline \multirow[t]{4}{*}{3} & $\begin{array}{l}\text { Ефективність впровадження } \\
\text { планової (задекларованої) } \\
\text { стратегії розвитку } \\
\text { досліджуваним підприємством } \\
\text { будівельної галузі (Effst), в т.ч. } \\
\text { за рахунок: }\end{array}$ & 0,8733 & 1 & 1 & 0,1267 & 0 \\
\hline & $\begin{array}{l}\text { Напрямок А - через } \\
\text { впровадження стратегії } \\
\text { концентрованого росту (збут } \\
\text { висококонкурентного портфелю } \\
\text { об'єктів нерухомості в рамках } \\
\text { первинного ринку нерухомого } \\
\text { житлового майна), \% } \\
\end{array}$ & 0,273 & 1 & 1 & 0,727 & 0 \\
\hline & $\begin{array}{l}\text { Напрямок В - через } \\
\text { впровадження стратегії } \\
\text { інтегрованого росту (освоєння } \\
\text { нових сегментів ринку } \\
\text { просування та збуту будівельної } \\
\text { продукції за рахунок охоплення } \\
\text { споживачів з низьким рівнем } \\
\text { доходів), \% }\end{array}$ & 0,393 & 1 & 1 & 0,607 & 0 \\
\hline & $\begin{array}{l}\text { Напрямок С - через } \\
\text { впровадження інноваційної } \\
\text { локальної стратегії, \% }\end{array}$ & 0,207 & 1 & 1 & 0,793 & 0 \\
\hline 3.1 .1 & додаткових факторів & 0 & 0 & 0 & 0 & 0 \\
\hline
\end{tabular}

Джерело: складено автором за матеріалами [4; 5; 6]

Відповідно до результатів розрахунків, можемо відзначити, що:

1) за 2015-2017 pp. ПрАТ «ХК «Київміськбуд» не здійснювало інвестицій в розвиток, оновлення основних засобів (обладнання), нематеріальних активів (технологій). Відповідно, це не було закладено на плановому стратегічному рівні. Незважаючи на відсутність інвестицій в розвиток, підприємство здійснює стратегічне планування та впроваджує: стратегію концентрованого росту (збут висококонкурентного портфелю об'єктів нерухомості в рамках первинного 
ринку нерухомого житлового майна); стратегію інтегрованого росту (освоєння нових сегментів ринку просування та збуту будівельної продукції за рахунок охоплення споживачів 3 низьким рівнем доходів); інноваційну локальну стратегію. Як видно 3 даних табл. 2, в 2015 р. найбільші обсяги доходів (виручки) від реалізації будівельної продукції у підприємства були за напрямком впровадження стратегії інтегрованого росту (освоєння нових сегментів ринку просування та збуту будівельної продукції за рахунок охоплення споживачів 3 низьким рівнем доходів)), що пов'язане із складною економічною ситуацією в країні. В 2016 р. найбільші обсяги доходів (виручки) від реалізації будівельної продукції у підприємства спостерігались за напрямком впровадження стратегії концентрованого росту (збут висококонкурентного портфелю об'єктів нерухомості в рамках первинного ринку нерухомого житлового майна), що обумовлено певним покращенням фінансово-економічної ситуації в країні, зростанням попиту на більш конкурентну нерухомість. В 2017 р. цей показник мав найбільші пріоритети за напрямком впровадження стратегії інтегрованого росту (освоєння нових сегментів ринку просування та збуту будівельної продукції за рахунок охоплення споживачів 3 низьким рівнем доходів)). Вказані переваги пояснюються внутрішньою міграцією населення категорії з низьким рівнем доходів;

б) ефективність впровадження планової (задекларованої) стратегії розвитку досліджуваним підприємством будівельної галузі (Effst) в 2015 р. складала 0,8733. Слід відмітити, що в 2015 р. найвище значення цього показника відмічено за напрямком впровадження стратегії інтегрованого росту (освоєння нових сегментів ринку просування та збуту будівельної продукції за рахунок охоплення споживачів з низьким рівнем доходів), що обумовлено меншою витратомісткістю порівняно 3 іншими напрямками. Незважаючи на зростання в 2016 р., 2017 р. показника ефективності впровадження планових (задекларованих) стратегій розвитку досліджуваним підприємством будівельної галузі (Effst), підприємство має перспективи його погіршення, якщо за умов зростання обсягів розвитку не буде здійснено оновлення обладнання та технологій. Визначені на стратегічному рівні стратегії, особливо, інноваційна локальна стратегія, не мали високої ефективності впровадження, в тому числі через відсутність інвестицій на їх реалізацію, недостатність власного потенціалу.

В табл. 3 подано визначення рівня ефективності впровадження планової (задекларованої) стратегії розвитку досліджуваним підприємством будівельної галузі (Effst) ПрАТ «Домобудівний комбінат № 4» (структурний елемент Корпорації «ДБК-ЖИТЛОБУД») (Creal) за 2015-2017 pp. 
Рівень ефективності впровадження планової (задекларованої) стратегії розвитку досліджуваним підприємством будівельної галузі (Effst) ПрАТ «Домобудівний комбінат № 4» (структурний елемент Корпорації «ДБК-ЖИТЛОБУД») (Creal) за 2015-2017 pp.

\begin{tabular}{|c|c|c|c|c|c|c|}
\hline \multirow[b]{2}{*}{$\begin{array}{l}\text { № } \\
\text { 3/ח }\end{array}$} & \multirow[b]{2}{*}{$\begin{array}{c}\text { Найменування оціночного } \\
\text { показника стратегії розвитку }\end{array}$} & \multirow[b]{2}{*}{2015 p. } & \multirow[b]{2}{*}{2016 p. } & \multirow[b]{2}{*}{2017 p. } & \multicolumn{2}{|c|}{ Зміна (+/-) } \\
\hline & & & & & $\begin{array}{l}\text { в } 2016 \text { р. } \\
\text { порівняно } 3 \\
2015 \text { р. } \\
\end{array}$ & $\begin{array}{l}\text { в } 2017 \text { p. } \\
\text { порівняно } 3 \\
2016 \text { p. }\end{array}$ \\
\hline 1 & $\begin{array}{l}\text { Звітні дані (2015-2017 рр. - результ } \\
\text { росту (ріст пропозицій будівельної пр } \\
\text { збільшення обсягів збуту в рамках ос }\end{array}$ & $\begin{array}{l}\text { т впровадж } \\
\text { оуукції в ра } \\
\text { өної ринко }\end{array}$ & $\begin{array}{l}\text { ння стратег } \\
\text { ках первинн } \\
\text { ї ніші) - на }\end{array}$ & $\begin{array}{l}\text { розвитку } \\
\text { го ринку не } \\
\text { рямок А) }\end{array}$ & $\begin{array}{l}\text { стратегії кон } \\
\text { ухомого жит }\end{array}$ & $\begin{array}{l}\text { еннтрованого } \\
\text { ового майна, }\end{array}$ \\
\hline 1.1 & $\begin{array}{l}\text { Обсяг доходу (виручки) від } \\
\text { реалізації будівельної продукції (Sdi } \\
(\mathrm{Cp} 11), \text { тис. грн. }\end{array}$ & 944214 & 1217133,6 & 1310410,8 & 272919,6 & 93277,2 \\
\hline 1.2 & $\begin{array}{l}\text { Обсяг } \quad \text { виробництва будівельної } \\
\text { продукції (Sdi (Cpl2), тис. грн. }\end{array}$ & 730022 & 936137 & 988677 & 206115 & 52540 \\
\hline 1.3 & $\begin{array}{l}\text { Обсяг чистого прибутку (Sdi (Cpl3), } \\
\text { тис. грн. }\end{array}$ & 8750 & 16728 & 35883 & 7978 & 19155 \\
\hline 1.4 & $\begin{array}{l}\text { Частка ринку (відношення обсягу } \\
\text { виробництва підприємства до } \\
\text { обсягу виробництва в галузі) (Sdi } \\
\text { (Cp14), тис. грн. }\end{array}$ & 1,269 & 1,270 & 0,936 & 0,001 & $-0,334$ \\
\hline 1.5 & $\begin{array}{l}\text { Звітна ефективність інвестицій (та } \\
\text { або оновлення основних засобів } \\
\text { (обладнання), } \\
\text { активів (технологій) за балансовою } \\
\text { вартістю)) в рамках впровадження } \\
\text { стратегії розвитку підприємства, } \\
\text { (Cinvrep), \% }\end{array}$ & 0 & 0 & 0 & 0 & 0 \\
\hline 2 & $\begin{array}{l}\text { Планові стратегічні дані (2015-2017 } \\
\text { стратегії концентрованого росту (ріс } \\
\text { нерухомого житлового майна, збільш }\end{array}$ & $\begin{array}{l}\text { p. - плануг } \\
\text { пропозиці } \\
\text { ння обсягів }\end{array}$ & $\begin{array}{l}\text { ння резуль? } \\
\text { будівельно } \\
\text { буту в рамк }\end{array}$ & $\begin{array}{l}\text { пу впрова } \\
\text { продукції } \\
\text { освоєної р }\end{array}$ & $\begin{array}{l}\text { ження страте } \\
\text { рамках перв } \\
\text { нкової ніші) }\end{array}$ & $\begin{array}{l}\text { ï розвитку - } \\
\text { нного ринку } \\
\text { напрямок А) }\end{array}$ \\
\hline 2.1 & $\begin{array}{l}\text { Обсяг доходу (виручки) від } \\
\text { реалізації будівельної продукції (Sdi } \\
(\mathrm{Cp} 11), \text { тис. грн. }\end{array}$ & 1217133,6 & 1310410,8 & 272919,6 & 93277,2 & $-1037491,2$ \\
\hline 2.2 & $\begin{array}{l}\text { Обсяг виробництва будівельної } \\
\text { продукції (Sdi (Cpl2), тис. грн. }\end{array}$ & 936137 & 988677 & 206115 & 52540 & -782562 \\
\hline 2.3 & $\begin{array}{l}\text { Обсяг чистого прибутку (Sdi (Cpl3), } \\
\text { тис. грн. }\end{array}$ & 16728 & 35883 & 7978 & 19155 & -27905 \\
\hline 2.4 & $\begin{array}{l}\text { Частка ринку (відношення обсягу } \\
\text { виробництва підприємства до } \\
\text { обсягу виробництва в галузі) (Sdi } \\
\text { (Cp14), тис. грн. }\end{array}$ & 1,270 & 0,936 & 0,001 & $-0,334$ & $-0,935$ \\
\hline 2.5 & 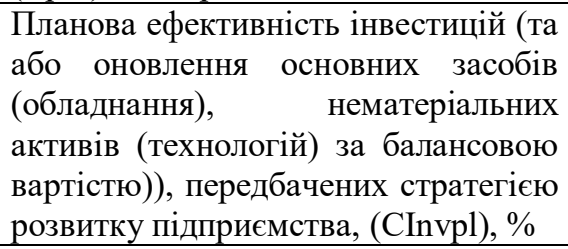 & 0 & 0 & 0 & 0 & 0 \\
\hline 3 & $\begin{array}{lr}\text { Ефективність } & \text { впровадження } \\
\text { планової (задекларованої) стратегії } \\
\text { розвитку } \\
\text { підприємством будівельної галузі } \\
\text { (Effst), в т.ч. за рахунок: } \\
\end{array}$ & 1 & 1 & 1 & 0 & 0 \\
\hline 3.1 .1 & додаткових факторів & 0 & 0 & 0 & 0 & 0 \\
\hline
\end{tabular}


Аналіз результатів розрахунків, наведених в табл. 3, свідчить, що:

1) впродовж 2015-2017 pp. ПрАТ «Домобудівний комбінат № 4» (структурний елемент Корпорації «ДБК-ЖИТЛОБУД») не забезпечило інвестицій в розвиток, оновлення основних засобів (обладнання), нематеріальних активів (технологій). Як показують результати стратегічного планування, інвестиції в розвиток не передбачались в прогнозних показниках. Хоча у підприємства і були відсутні інвестиції в розвиток, спостерігалось стратегічне планування та впровадження стратегії розвитку - стратегії концентрованого росту (ріст пропозицій будівельної продукції в рамках первинного ринку нерухомого житлового майна, збільшення обсягів збуту в рамках освоєної ринкової ніші). Підприємство не орієнтоване на впровадження інноваційних заходів в рамках вказаних стратегій розвитку, що підтверджується відсутністю відповідних інвестицій;

2) за 2015-2017 рр. ПрАТ «Домобудівний комбінат № 4» (структурний елемент Корпорації «ДБК-ЖИТЛОБУД») демонструє значення ефективності впровадження планової (задекларованої) стратегії розвитку (Effst) на рівні 1, тобто, на середньому, не змінному рівні. Таке значення показника вказує на виконання стратегічних планових показників, але відсутність синергетизму, прогресу. Останнє обумовлене недостатнім забезпеченням технологій, обладнання. Факт відсутності інвестицій за умов невпинного зростання показників стратегічного розвитку на підприємстві свідчить про можливість перспектив втрати рівня технологічності, забезпеченості обладнанням для цілей реалізації стратегій тощо. В табл. 4 наведено розрахунок рівня ефективності впровадження планової (задекларованої) стратегії розвитку досліджуваним підприємством будівельної галузі (Effst) ПрАТ «Завод залізобетонних конструкцій № 1» (Creal) за 2015-2017 pp.

Таблиия 4

Рівень ефективності впровадження планової (задекларованої) стратегії розвитку досліджуваним підприємством будівельної галузі (Effst) ПрАТ «Завод залізобетонних конструкцій №1» (Creal) за 2015-2017 pp.

\begin{tabular}{|c|c|c|c|c|c|c|}
\hline \multirow[b]{2}{*}{$\begin{array}{l}\text { № } \\
\text { 3/ח }\end{array}$} & \multirow[b]{2}{*}{$\begin{array}{l}\text { Найменування оціночного показника } \\
\text { стратегії розвитку }\end{array}$} & \multirow[b]{2}{*}{$2015 \mathrm{p}$} & \multirow[b]{2}{*}{2016 p. } & \multirow[b]{2}{*}{2017 p. } & \multicolumn{2}{|c|}{ Зміна (+/-) } \\
\hline & & & & & $\begin{array}{l}\text { в } 2016 \mathrm{p} . \\
\text { порівняно } \\
32015 \text { р. }\end{array}$ & $\begin{array}{l}\text { в } 2017 \mathrm{p} . \\
\text { порівняно } 3 \\
2016 \text { p. }\end{array}$ \\
\hline 1 & 2 & 3 & 4 & 5 & 6 & 7 \\
\hline 1 & $\begin{array}{l}\text { Звітні дані (2015-2017 pp. - результат впров } \\
\text { (забезпечення зростання обсягів виробн } \\
\text { підприємства (житлових будинків } 3 \text { вла } \\
\text { потужностей) в рамках освоєної ринкової ніі }\end{array}$ & $\begin{array}{l}\text { ження ст } \\
\text { цтва та } \\
\text { их мате } \\
\text { - напря }\end{array}$ & $\begin{array}{l}\text { еегії розв } \\
\text { еалізації } \\
\text { лів, які } \\
\text { к А) }\end{array}$ & $y-c T$ & $\begin{array}{l}\text { і концентр } \\
\text { будівель } \\
\text { ся на ба }\end{array}$ & $\begin{array}{l}\text { ваного росту } \\
\text { i продукції } \\
\text { заводськких }\end{array}$ \\
\hline 1.1 & $\begin{array}{l}\text { Обсяг доходу (виручки) від реалізації } \\
\text { будівельної продукції (Sdi (Cpl1), тис. грн. }\end{array}$ & 165726 & 257652 & 379561,2 & 91926 & 121909,2 \\
\hline 1.2 & $\begin{array}{l}\text { Обсяг виробництва будівельної продукції } \\
\text { (Sdi (Cpl2), тис. грн. }\end{array}$ & 110682 & 168952 & 253902 & 58270 & 84950 \\
\hline 1.3 & $\begin{array}{l}\text { Обсяг чистого прибутку (Sdi (Cpl3), тис. } \\
\text { грн. }\end{array}$ & 1136 & 11704 & 29656 & 10568 & 17952 \\
\hline 1.4 & $\begin{array}{l}\text { Частка ринку (відношення } \\
\text { виробництва підприємства до обу } \\
\text { виробництва в галузі) (Sdi (Cpl4), тис. грн. }\end{array}$ & 0,192 & 0,229 & 0,240 & 0,037 & 0,011 \\
\hline
\end{tabular}


Продовження таблиці 4

\begin{tabular}{|c|c|c|c|c|c|c|}
\hline 1 & 2 & 3 & 4 & 5 & 6 & 7 \\
\hline 1.5 & 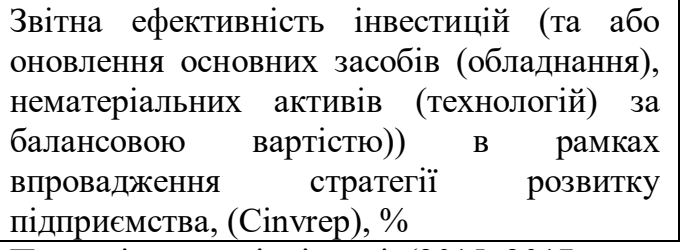 & 0 & 0 & 0 & 0 & 0 \\
\hline 2 & $\begin{array}{l}\text { Планові стратегічні дані (2015-2017 pp. - } \\
\text { стратегії концентрованого росту (забезпечен } \\
\text { будівельної продукції підприємства (житлов } \\
\text { заводських потужностей) в рамках освоєної } \mathrm{p}\end{array}$ & $\begin{array}{l}\text { лануванн } \\
\text { я зростан } \\
\text { будинкі } \\
\text { нкової ні }\end{array}$ & $\begin{array}{l}\text { власних } \\
- \text { напр }\end{array}$ & $\begin{array}{l}\text { впровадж } \\
\text { иробництв } \\
\text { гатеріалів, } \\
\text { ок А) }\end{array}$ & ся стр & $\begin{array}{l}\text { розвитку - } \\
\text { радиційної } \\
\text { гься на базі }\end{array}$ \\
\hline 2.1 & $\begin{array}{l}\text { Обсяг доходу (виручки) від реалізації } \\
\text { будівельної продукції (Sdi (Cpl1), тис. грн. }\end{array}$ & 165726 & 257652 & 379561,2 & 91926 & 121909,2 \\
\hline 2.2 & $\begin{array}{l}\text { Обсяг виробництва будівельної продукції } \\
\text { (Sdi (Cpl2), тис. грн. }\end{array}$ & 110682 & 168952 & 253902 & 58270 & 84950 \\
\hline 2.3 & $\begin{array}{l}\text { Обсяг чистого прибутку (Sdi (Cpl3), тис. } \\
\text { грн. }\end{array}$ & 1136 & 11704 & 29656 & 10568 & 17952 \\
\hline 2.4 & $\begin{array}{l}\text { Частка ринку (відношення } \\
\text { виробництва пбсягу } \\
\text { виробництва в галузі) (Sdi (Cpl4), тис. грн. }\end{array}$ & 0,192 & 0,229 & 0,240 & 0,037 & 0,011 \\
\hline 2.5 & $\begin{array}{l}\text { Планова ефективність інвестицій (та або } \\
\text { оновлення основних засобів (обладнання), } \\
\text { нематеріальних активів (технологій) за } \\
\text { балансовою вартістю)), передбачених } \\
\text { стратегією розвитку підприємства, (CInvpl), } \\
\text { \% }\end{array}$ & 0 & 0 & 0 & 0 & 0 \\
\hline 3 & $\begin{array}{l}\text { Ефективність впровадження } \\
\text { (задекларованої) } \quad \text { планової } \\
\text { досліджудії } \\
\text { галузі (Effst), в т.ч. за развитку } \\
\text { гахунок: }\end{array}$ & 1 & 1 & 1 & 0 & 0 \\
\hline 3.1 . & додаткових факторів & 0 & 0 & 0 & 0 & 0 \\
\hline
\end{tabular}

Джерело: складено автором за матеріалами [9; 10]

Оцінка результатів розрахунків, поданих в табл. 4, дозволяє констатувати наступне, зокрема:

1) за період 2015-2017 рр. ПрАТ «Завод залізобетонних конструкцій № 1» не здійснювало та не планувало інвестицій в розвиток, оновлення основних засобів (обладнання), нематеріальних активів (технологій), що використовуються для впровадження стратегій. За цей період досліджуване підприємство визначило та впроваджувало на стратегічному рівні стратегію розвитку - стратегію концентрованого росту (забезпечення зростання обсягів виробництва та реалізації традиційної будівельної продукції підприємства (житлових будинків 3 власних матеріалів, які виготовляються на базі заводських потужностей) в рамках освоєної ринкової ніші). Всі стратегічні заходи були визначені на базі використання існуючих технологій, обладнання, i, відповідно, реалізація цієї стратегії відбувалась в рамках наявних можливостей. У підприємства відсутні інноваційні підходи до стратегічного планування та реалізації стратегій розвитку, що пояснюється відсутністю інвестицій в розвиток;

2) впродовж 2015-2017 рр. значення ефективності впровадження планової (задекларованої) стратегії розвитку досліджуваним підприємством будівельної галузі ПрАТ «Завод залізобетонних конструкцій № 1» (Effst) було на рівні 1, 
яке відповідає середньому рівню. Вказане значення свідчить про виконання стратегічних планових показників, відсутність прогресу, синергетичного ефекту від впливу додаткових факторів. У великій мірі такий результат можемо пояснити відсутністю інвестиційного розвитку, оновлення основних засобів, обладнання, які використовуються для впровадження стратегії. Відповідно, підприємство демонструє зростання в умовах зношуваності технологічного обладнання, технологій, що використовуються в процесі впровадження обраної стратегій розвитку.

В табл. 5 представлено розрахунок рівня ефективності впровадження планової (задекларованої) стратегії розвитку досліджуваним підприємством будівельної галузі (Effst) ТОВ «Астроінвест-Енерджі» (Creal) за 2015-2017 pp.

Таблиия 5

Рівень ефективності впровадження планової (задекларованої) стратегії розвитку досліджуваним підприємством будівельної галузі (Effst) TOB «Астроінвест-Енерджі»

(Creal) 3a 2015-2017 pp.

\begin{tabular}{|c|c|c|c|c|c|c|}
\hline \multirow[b]{2}{*}{ № 3/ח } & \multirow[b]{2}{*}{$\begin{array}{l}\text { Найменування оціночного } \\
\text { показника стратегії розвитку }\end{array}$} & \multirow[b]{2}{*}{2015 p. } & \multirow[b]{2}{*}{2016 p. } & \multirow[b]{2}{*}{2017 p. } & \multicolumn{2}{|c|}{ Зміна (+/-) } \\
\hline & & & & & $\begin{array}{l}\text { в } 2016 \mathrm{p} . \\
\text { порівняно з } \\
2015 \text { р. }\end{array}$ & $\begin{array}{l}\text { в } 2017 \text { p. } \\
\text { порівняно } 3 \\
2016 \text { р. }\end{array}$ \\
\hline 1 & 2 & 3 & 4 & 5 & 6 & 7 \\
\hline 1 & $\begin{array}{l}\text { Звітні дані }(2015-2017 \text { pp. - pез } \\
\text { росту (збільшення обсягів виро } \\
\text { газотранспортної системи) в рам }\end{array}$ & $\begin{array}{l}\text { ьтат впрог } \\
\text { ицтва та } \\
\text { х освоєної }\end{array}$ & $\begin{array}{l}\text { кення стр } \\
\text { лізації об } \\
\text { нкової ніш }\end{array}$ & $\begin{array}{l}\text { гії розвить } \\
\text { сів інжене } \\
\text { - напрямог }\end{array}$ & $\begin{array}{l}\text { - стратегії ко1 } \\
\text { ої інфраструк }\end{array}$ & $\begin{array}{l}\text { ентрованого } \\
\text { ри (об'єктів }\end{array}$ \\
\hline 1.1 & $\begin{array}{l}\text { Обсяг доходу (виручки) від } \\
\text { реалізації будівельної продукції } \\
\text { (Sdi (Cpl1), тис. грн. }\end{array}$ & 232927,2 & 274938 & 293883,6 & 42010,8 & 18945,6 \\
\hline 1.2 & $\begin{array}{l}\text { Обсяг виробництва будівельної } \\
\text { продукції (Sdi (Cpl2), тис. грн. }\end{array}$ & 165520 & 215085 & 220367 & 49565 & 5282 \\
\hline 1.3 & $\begin{array}{l}\text { Обсяг чистого прибутку (Sdi } \\
(\mathrm{Cp} 13) \text {, тис. грн. }\end{array}$ & -501504 & -492784 & -25707 & 8720 & 467077 \\
\hline 1.4 & 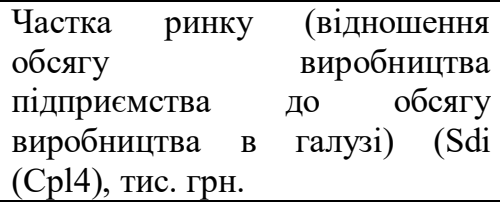 & 0,288 & 0,292 & 0,209 & 0,004 & $-0,083$ \\
\hline 1.5 & 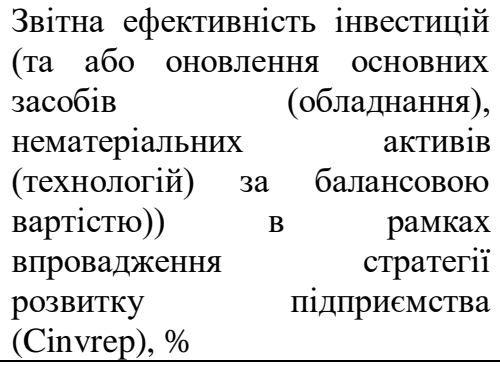 & 0 & 0 & 0 & 0 & 0 \\
\hline 2 & $\begin{array}{l}\text { Планові стратегічні дані (2015-2 } \\
\text { стратегії концентрованого росту } \\
\text { інфраструктури (об’єктів газотра }\end{array}$ & $\begin{array}{l}17 \text { pp. - I } \\
\text { збільшен } \\
\text { портної с }\end{array}$ & $\begin{array}{l}\text { ування р } \\
\text { осягів в } \\
\text { ми) в ра }\end{array}$ & $\begin{array}{l}\text { ттату впр } \\
\text { ництва тс } \\
\text { освоєноі }\end{array}$ & $\begin{array}{l}\text { дження страте } \\
\text { алізації об’єкт } \\
\text { Ікової ніші) - }\end{array}$ & $\begin{array}{l}\text { ї розвитку - } \\
\text { інженерної } \\
\text { ппрямок А) }\end{array}$ \\
\hline 2.1 & $\begin{array}{l}\text { Обсяг доходу (виручки) від } \\
\text { реалізації будівельної продукції } \\
\text { (Sdi (Cpl1), тис. грн. }\end{array}$ & 232927,2 & 274938 & 293883,6 & 42010,8 & 18945,6 \\
\hline 2.2 & $\begin{array}{l}\text { Обсяг виробництва будівельної } \\
\text { продукції (Sdi (Cpl2), тис. грн. }\end{array}$ & 165520 & 215085 & 220367 & 49565 & 5282 \\
\hline
\end{tabular}




\begin{tabular}{|c|c|c|c|c|c|c|}
\hline 1 & 2 & 3 & 4 & 5 & 6 & 7 \\
\hline 2.3 & $\begin{array}{l}\text { Обсяг чистого прибутку (Sdi } \\
\text { (Cpl3), тис. грн. }\end{array}$ & $-351052,8$ & $-70210,56$ & 2520 & 280842,24 & 72730,56 \\
\hline 2.4 & \begin{tabular}{llr} 
Частка ринку & \multicolumn{2}{c}{ (відношення } \\
обсягу & \multicolumn{2}{c}{ виробництва } \\
підприємства & \multicolumn{2}{c}{ до обсягу } \\
виробництва в & галузі) & (Sdi \\
(Cpl4), тис. грн. & &
\end{tabular} & 0,288 & 0,292 & 0,209 & 0,004 & $-0,083$ \\
\hline 2.5 & 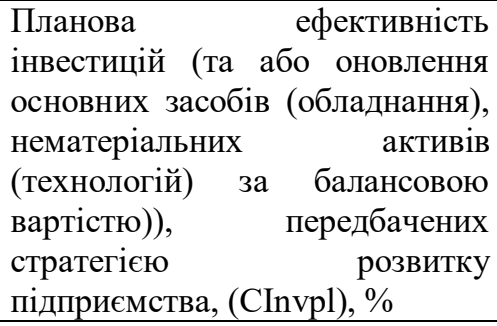 & 0 & 0 & 0 & 0 & 0 \\
\hline 3 & $\begin{array}{lr}\text { Ефективність } & \text { впровадження } \\
\text { планової } & \text { (задекларованої) } \\
\text { стратегії } & \text { розвитку } \\
\text { досліджуваним } & \text { підприємством } \\
\text { будівельної галузі (Effst), в т.ч. } \\
\text { за рахунок: } \\
\end{array}$ & 1,429 & 7,019 & $-10,201$ & 5,59 & $-17,22$ \\
\hline 3.1 .1 & додаткових факторів & 0 & 0 & 0 & 0 & 0 \\
\hline
\end{tabular}

Вивчення результатів табл. 5 дає можливість зробити наступні висновки, a came:

1) впродовж 2015-2017 pp. ТОВ «Астроінвест-Енерджі» на стратегічному та рівні впровадження стратегій не здійснювало інвестицій в розвиток, не оновлювало основних засобів, технологій, які використовуються в процесі впровадження стратегічних параметрів. Як і у випадку попередніх чотирьох підприємств, ТОВ «Астроінвест-Енерджі» реалізує стратегію розвитку, не забезпечену інвестиційними ресурсами. На стратегічному рівні було заплановано та на фактичному рівні впроваджено стратегію розвитку стратегію концентрованого росту (збільшення обсягів виробництва та реалізації об’єктів інженерної інфраструктури (об’єктів газотранспортної системи) в рамках освоєної ринкової ніші);

2) значення ефективності впровадження планової (задекларованої) стратегії розвитку досліджуваним підприємством будівельної галузі ТОВ «Астроінвест-Енерджі» (Effst) за період 2015-2016 рр. знаходилось на рівні більше 1. Здійснюється висновок щодо забезпечення позапланової ефективності впровадження стратегії розвитку та дії додаткових факторів впливу. В 2017 р. цей показник вже на рівні менше 0. Встановлюється факт відсутності досягнення стратегічних планових показників на рівні досліджуваного будівельного підприємства.

Відповідно, зазначені результати, як і за даними аналізу попередніх досліджуваних підприємств будівельної галузі України, пов'язані із тим, що для стратегічного планування та реалізації стратегій розвитку не передбачається інвестування, яке б сприяло ефективному функціонуванню. Власні потужності не оновлюються тривалий час, що може стати причиною 
невідповідності впровадження стратегічних параметрів розвитку в перспективі. Одним із свідчень цього $\epsilon$ невідповідність фінансового результату від функціонування, отриманого підприємством за результатами впровадження стратегіiі. Представлена картина стану та трансформацій рівня ефективності впровадження планових (задекларованих) стратегій розвитку досліджуваних найбільших підприємств будівельної галузі України впродовж 2015-2017 pp. дозволяє сформулювати основні положення історіографії становлення цієї сфери за вказаний період, серед яких, зокрема: відсутність інвестицій в розвиток, незважаючи на потреби оновлення основних засобів та технологій, що використовуються для впровадження стратегічних параметрів; недостатнє впровадження інновацій в сфері управління методами будівництва, управлінні відходами, управлінні енергоефективністю будівельної продукції та будівництва (встановлено, що тільки два (ДП АТ «БК «Укрбуд» та ПрАТ «ХК «Київміськбуд») 3 п’яти підприємств використовують інновації, i лише одне забезпечує їх ефективне впровадження (а саме, ДП АТ «БК «Укрбуд»)).

В табл. 6 наведено порядок оцінки найбільш вагомого впливу факторів на рівень ефективності впровадження стратегій досліджуваних підприємств будівельної галузі країни.

Таблиия 6

Порядок оцінки найбільш вагомого впливу факторів на рівень ефективності впровадження стратегій досліджуваних підприсмств будівельної галузі країни

\begin{tabular}{|c|}
\hline 1-й етап \\
\hline$\downarrow$ \\
\hline $\begin{array}{c}\text { Визначення загального рівня впливу зовнішніх факторів на розвиток будівельної галузі } \\
\text { України (Е) (y \%) }\end{array}$ \\
\hline$\downarrow$ \\
\hline 2-й етап \\
\hline$\downarrow$ \\
\hline $\begin{array}{c}\text { Визначення загального рівня впливу внутрішніх факторів на розвиток будівельної галузі } \\
\text { України (CI) (y \%) }\end{array}$ \\
\hline$\downarrow$ \\
\hline 3-й етап \\
\hline$\downarrow$ \\
\hline $\begin{array}{c}\text { Визначення загального рівня впливу міжнародних факторів на розвиток будівельної галузі } \\
\text { України (I) (у \%) }\end{array}$ \\
\hline$\downarrow$ \\
\hline 4-й етап \\
\hline$\downarrow$ \\
\hline $\begin{array}{l}\text { Визначення рівня впливу додаткових внутрішніх факторів суб’єктів будівельної галузі країни } \\
\text { (AЕ) (табл. } 1 \text { - 5) (у \%) }\end{array}$ \\
\hline$\downarrow$ \\
\hline 5-й етап \\
\hline$\downarrow$ \\
\hline $\begin{array}{c}\text { Визначення загального впливу факторів за основними категоріями (у вигляді формули } \\
\text { впливу) }(\mathrm{CF}) \text {. Встановлення позитивного }(+) \text {, негативного (-) впливів за певними категоріями } \\
\text { факторів, вивчення трансформації їх зміни (у \%) }\end{array}$ \\
\hline
\end{tabular}

Джерело: авторська розробка 
На другому етапі проведемо оцінку найбільш вагомого впливу факторів на рівень ефективності впровадження стратегій досліджуваних підприємств впродовж 2015-2017 рр. Для вказаних цілей можна запропонувати авторське бачення до оцінки, що базується на інтеграції підходів до оцінки впливу зовнішніх факторів на розвиток будівельної галузі країни, впливу загальних внутрішніх факторів на розвиток будівельної галузі країни, впливу міжнародних факторів на розвиток будівельної галузі країни, впливу додаткових внутрішніх факторів суб'єктів будівельної галузі країни (табл. 1-5).

За результатами представленого авторського підходу (табл. 6) в дослідженні передбачено визначення загального впливу факторів дії, відповідних для будівельної галузі та впливу додаткових внутрішніх факторів суб'єктів будівельної галузі країни впродовж 2015-2017рр. Відповідно до умов зазначеного підходу, оцінка впливу комплексу зазначених факторів розвитку підприємств будівельної галузі України досліджується через їх позитивну або негативну дію на стан ефективності впровадження планових (задекларованих) стратегій розвитку.

Керуючись вказаним методичним порядком (табл. 6), проведемо розрахунок найбільш вагомого впливу факторів на рівень ефективності впровадження стратегій досліджуваних підприємств впродовж періоду 2015-2017 pр. (табл. 7).

Таблиия 7

Вплив факторів на рівень ефективності впровадження стратегій досліджуваних підприємств будівельної галузі України впродовж 2015-2017 pp.

\begin{tabular}{|c|c|c|c|c|}
\hline \multirow{2}{*}{$\begin{array}{l}\text { № } \\
\text { 3/п }\end{array}$} & \multirow{2}{*}{ Найменування будівельного підприємства } & \multicolumn{3}{|c|}{ Формула впливу факторів } \\
\hline & & $2015 \mathrm{p}$. & $2016 \mathrm{p}$. & $2017 \mathrm{p}$. \\
\hline 1 & 2 & 3 & 4 & 5 \\
\hline \multirow[t]{6}{*}{1} & ДП АТ «БК «Укрбуд» & $\begin{array}{c}-71,134 \mathrm{E}-7,31 \mathrm{CI}- \\
20,34 \mathrm{I}+100 \mathrm{AE}\end{array}$ & $\begin{array}{c}-56,329 \mathrm{E}- \\
2,65 \mathrm{CI}-7,16 \mathrm{I}+ \\
100 \mathrm{AE}\end{array}$ & $\begin{array}{c}-15,561 \mathrm{E}+ \\
5,32 \mathrm{CI}-3,96 \mathrm{I}+ \\
100 \mathrm{AE}\end{array}$ \\
\hline & $\begin{array}{l}\text { Вплив зовнішніх факторів на розвиток } \\
\text { будівельної галузі України (Е), (y \%) }\end{array}$ & $-71,134$ & $-56,329$ & $-15,561$ \\
\hline & $\begin{array}{l}\text { Вплив загальних внутрішніх факторів на } \\
\text { розвиток будівельної галузі України (СI), (у } \\
\%)\end{array}$ & $-7,31$ & $-2,65$ & 5,32 \\
\hline & $\begin{array}{l}\text { Вплив міжнародних факторів на розвиток } \\
\text { будівельної галузі України (I), (у \%) }\end{array}$ & $-20,34$ & $-7,16$ & $-3,96$ \\
\hline & $\begin{array}{l}\text { Вплив додаткових внутрішніх факторів } \\
\text { суб'єкта будівельної галузі країни (AЕ), (у } \\
\%)\end{array}$ & 100 & 100 & 100 \\
\hline & $\begin{array}{l}\text { Загальний вплив факторів за основними } \\
\text { категоріями (CF), (y \%) }\end{array}$ & 1,216 & 33,861 & 85,799 \\
\hline \multirow[t]{3}{*}{2} & ПрАТ «ХК «Київміськбуд» & $\begin{array}{c}-71,134 \mathrm{E}-7,31 \mathrm{CI}- \\
20,34 \mathrm{I}+0 \mathrm{AE}\end{array}$ & $\begin{array}{c}-56,329 \mathrm{E}- \\
2,65 \mathrm{CI}-7,16 \mathrm{I}+ \\
0 \mathrm{AE}\end{array}$ & $\begin{array}{c}-15,561 \mathrm{E}+ \\
5,32 \mathrm{CI}-3,96 \mathrm{I}+ \\
0 \mathrm{AE}\end{array}$ \\
\hline & $\begin{array}{l}\text { Вплив зовнішніх факторів на розвиток } \\
\text { будівельної галузі України (Е), (у \%) }\end{array}$ & $-71,134$ & $-56,329$ & $-15,561$ \\
\hline & $\begin{array}{l}\text { Вплив загальних внутрішніх факторів на } \\
\text { розвиток будівельної галузі України (CI), (у } \\
\%)\end{array}$ & $-7,31$ & $-2,65$ & 5,32 \\
\hline
\end{tabular}


Продовження таблиці 7

\begin{tabular}{|c|c|c|c|c|}
\hline 1 & 2 & 3 & 4 & 5 \\
\hline & $\begin{array}{l}\text { Вплив міжнародних факторів на розвиток } \\
\text { будівельної галузі України (I), (у \%) }\end{array}$ & $-20,34$ & $-7,16$ & $-3,96$ \\
\hline & $\begin{array}{l}\text { Вплив додаткових внутрішніх факторів } \\
\text { суб'єкта будівельної галузі країни (AЕ), (у } \\
\%)\end{array}$ & 0 & 0 & 0 \\
\hline & $\begin{array}{l}\text { Загальний вплив факторів за основними } \\
\text { категоріями }(\mathrm{CF}),(\mathrm{y} \%)\end{array}$ & $-98,784$ & $-66,139$ & $-14,201$ \\
\hline \multirow[t]{6}{*}{3} & $\begin{array}{l}\text { ПрАТ «Домобудівний } \\
\text { (структурний елемемент } \\
\text { ЖИТЛОБУнат } \\
\text { Корпорації }\end{array}$ & $\begin{array}{c}-71,134 \mathrm{E}-7,31 \mathrm{CI}- \\
20,34 \mathrm{I}+0 \mathrm{AE}\end{array}$ & $\begin{array}{l}-56,329 \mathrm{E}- \\
2,65 \mathrm{CI}-7,16 \mathrm{I}+ \\
0 \mathrm{AE}\end{array}$ & $\begin{array}{c}-15,561 \mathrm{E}+ \\
5,32 \mathrm{CI}-3,96 \mathrm{I}+ \\
0 \mathrm{AE}\end{array}$ \\
\hline & $\begin{array}{l}\text { Вплив зовнішніх факторів на розвиток } \\
\text { будівельної галузі України (Е), (у \%) }\end{array}$ & $-71,134$ & $-56,329$ & $-15,561$ \\
\hline & $\begin{array}{l}\text { Вплив загальних внутрішніх факторів на } \\
\text { розвиток будівельної галузі України (CI), (у } \\
\%)\end{array}$ & $-7,31$ & $-2,65$ & 5,32 \\
\hline & $\begin{array}{l}\text { Вплив міжнародних факторів на розвиток } \\
\text { будівельної галузі України (I), (у \%) }\end{array}$ & $-20,34$ & $-7,16$ & $-3,96$ \\
\hline & $\begin{array}{l}\text { Вплив додаткових внутрішніх факторів } \\
\text { суб'єкта будівельної галузі країни (AЕ), (у } \\
\%)\end{array}$ & 0 & 0 & 0 \\
\hline & $\begin{array}{l}\text { Загальний вплив факторів за основними } \\
\text { категоріями }(\mathrm{CF}),(\mathrm{y} \%)\end{array}$ & $-98,784$ & $-66,139$ & $-14,201$ \\
\hline \multirow[t]{6}{*}{4} & $\begin{array}{l}\text { ПрАТ «Завод залізобетонних конструкцій } \\
\text { № 1» }\end{array}$ & $\begin{array}{c}-71,134 \mathrm{E}-7,31 \mathrm{CI}- \\
20,34 \mathrm{I}+0 \mathrm{AE}\end{array}$ & $\begin{array}{c}-56,329 \mathrm{E}- \\
2,65 \mathrm{CI}-7,16 \mathrm{I}+ \\
0 \mathrm{AE}\end{array}$ & $\begin{array}{c}-15,561 \mathrm{E}+ \\
5,32 \mathrm{CI}-3,96 \mathrm{I}+ \\
0 \mathrm{AE}\end{array}$ \\
\hline & $\begin{array}{l}\text { Вплив зовнішніх факторів на розвиток } \\
\text { будівельної галузі України (Е), (у \%) }\end{array}$ & $-71,134$ & $-56,329$ & $-15,561$ \\
\hline & $\begin{array}{l}\text { Вплив загальних внутрішніх факторів на } \\
\text { розвиток будівельної галузі України (CI), (у } \\
\%)\end{array}$ & $-7,31$ & $-2,65$ & 5,32 \\
\hline & $\begin{array}{l}\text { Вплив міжнародних факторів на розвиток } \\
\text { будівельної галузі України (I), (у \%) }\end{array}$ & $-20,34$ & $-7,16$ & $-3,96$ \\
\hline & $\begin{array}{l}\text { Вплив додаткових внутрішніх факторів } \\
\text { суб'єкта будівельної галузі країни (AЕ), (у } \\
\text { \%) }\end{array}$ & 0 & 0 & 0 \\
\hline & $\begin{array}{l}\text { Загальний вплив факторів за основними } \\
\text { категоріями }(\mathrm{CF}),(\mathrm{y} \%)\end{array}$ & $-98,784$ & $-66,139$ & $-14,201$ \\
\hline \multirow[t]{6}{*}{5} & ТОВ «Астроінвест-Енерджі» & $\begin{array}{c}-71,134 \mathrm{E}-7,31 \mathrm{CI}- \\
20,34 \mathrm{I}+0 \mathrm{AE}\end{array}$ & $\begin{array}{c}-56,329 \mathrm{E}- \\
2,65 \mathrm{CI}-7,16 \mathrm{I}+ \\
0 \mathrm{AE}\end{array}$ & $\begin{array}{c}-15,561 \mathrm{E}+ \\
5,32 \mathrm{CI}-3,96 \mathrm{I}+ \\
0 \mathrm{AE}\end{array}$ \\
\hline & $\begin{array}{l}\text { Вплив зовнішніх факторів на розвиток } \\
\text { будівельної галузі України (Е), (у \%) }\end{array}$ & $-71,134$ & $-56,329$ & $-15,561$ \\
\hline & $\begin{array}{l}\text { Вплив загальних внутрішніх факторів на } \\
\text { розвиток будівельної галузі України (CI), (у } \\
\% \text { ) }\end{array}$ & $-7,31$ & $-2,65$ & 5,32 \\
\hline & $\begin{array}{l}\text { Вплив міжнародних факторів на розвиток } \\
\text { будівельної галузі України (I), (у \%) }\end{array}$ & $-20,34$ & $-7,16$ & $-3,96$ \\
\hline & $\begin{array}{l}\text { Вплив додаткових внутрішніх факторів } \\
\text { суб'єкта будівельної галузі країни (AЕ), (у } \\
\%)\end{array}$ & 0 & 0 & 0 \\
\hline & $\begin{array}{l}\text { Загальний вПлив факторів за основними } \\
\text { категоріями }(\mathrm{CF}),(\mathrm{y} \%)\end{array}$ & $-98,784$ & $-66,139$ & $-14,201$ \\
\hline
\end{tabular}

\section{Джерело: складено автором}

Згідно $з$ даними оцінки, представленими в табл. 7, можемо констатувати наступне, зокрема: 1) ДП АТ «БК «Укрбуд» - єдина 3 досліджуваних будівельних компаній, яка змогла забезпечити ефективність стратегічного розвитку, використовуючи власні ресурси. За результатами оцінки впливу 
зазначених факторів на стан ефективності впровадження стратегії розвитку можна відмітити позитивний вплив. Це було пов'язано у великій мірі 3 успішним синергетичним впливом додаткового внутрішнього фактору позапланове впровадження інновацій в сфері управління будівництвом. Найбільш ефективним був вплив факторів в 2017 р., коли завдяки скороченню негативної дії зовнішніх та міжнародних, покращенню загальних внутрішніх, підприємство демонструвало високий ефект від внутрішніх додаткових факторів. Відповідно, ДП АТ «БК «Укрбуд» змогло забезпечити протидію зовнішнім, загальним внутрішнім (галузевим) та міжнародним факторам, використавши внутрішній потенціал та успішно реалізувавши впровадження інновацій; 2) інші чотири досліджуваних підприємства будівельної галузі не демонстрували в процесі впровадження стратегій розвитку додаткових внутрішніх факторів і це не дало змоги їм протистояти впливу зовнішніх, загальних внутрішніх (галузевих) та міжнародних факторів. Як свідчить аналіз, впродовж трьох років скорочувався негативний вплив цих факторів, який переважав над позитивним, i це, в свою чергу дало можливість в 2016 p., 2017 р. повністю реалізувати стратегічні плани всім підприємствам. В 2015 р. через високий вплив вказаних факторів ПрАТ «ХК «Київміськбуд» не змогло реалізувати повністю запланованих стратегічних параметрів за всіма напрямками розвитку.

Висновки 3 проведеного дослідження. Представлене дослідження дозволяє оцінити рівень внутрішнього опору впливу зовнішніх, загальних внутрішніх (галузевих) та міжнародних факторів 3 боку найбільших підприємств будівельної галузі України впродовж 2015-2017 рр. Картина стану впливу цих факторів є історіографією стратегічного розвитку суб'єктів галузі протягом вказаного періоду, яка може бути використана для порівняння за параметрами розвитку щодо протидії факторного впливу для інших підприємств в цій сфері (середніх, малих тощо). Встановлена картина впливу факторів обумовлена стратегічним розвитком найбільших підприємств, положення якого визначені в процесі оцінки рівня ефективності впровадження стратегій розвитку. Доведено, що єдиним підприємством, яке має високий рівень ефективності впровадження стратегій розвитку, виступає ДП АТ «БК «Укрбуд», яке, в свою чергу, характеризується високим опором факторного впливу.

\section{Перелік посилань}

1. Державне публічне акціонерне товариство «Будівельна компанія «Укрбуд». URL: https://smida.gov.ua/db/participant/33298371 (дата звернення: 08.06.2019).

2. Річна інформація емітента цінних паперів (річний звіт) ДП АТ «БК «Укрбуд» за 2018 p. URL: https://kmb.ua/wpcontent/uploads/2019/04/zv\%D1\%96t-kmb-za-2018-r\%D1\%96k.pdf (дата звернення: 08.06.2019). 
3. УКРБУД розповів про тренди та інновації в будівництві на II ForumRED. URL: https://ub.com.ua/news/ukrbud-rozpoviv-pro-trendi-ta-innovatsijiv-budivnitstvi-na-ii-forumred (дата звернення: 08.06.2019).

4. Звіти Київміськбуд. URL: https://kmb.ua/ua/about/corporateinformation/otchety/ (дата звернення: 08.06.2019).

5. Київміськбуд. Річний звіт 2018. URL: https://kmb.ua/wpcontent/uploads/2019/06/kmb_3105.pdf (дата звернення: 08.06.2019).

6. Приватне акціонерне товариство «Холдингова компанія «Київміськбуд».

URL: https://kmb.ua/ua/?gclid=Cj0KCQjwov3nBRDFARIsANgsdoHhg_o2vlOpuGCehwY uwAI0jU_n_3EjyQHIgTupcWkIL4wQY1dNBDAaAjpvEALw_wcB (дата звернення: 08.06.2019).

7. Корпорація «ДБК-ЖИТЛОБУД». URL: https://dbkzhytlobud.com.ua/ua/ (дата звернення: 08.06.2019).

8. Приватне акціонерне товариство «Домобудівний комбінат № 4». URL: https://smida.gov.ua/db/participant/05503160 (дата звернення: 08.06.2019).

9. Приватне акціонерне товариство "Завод залізобетонних конструкцій № 1". URL: https://smida.gov.ua/db/participant/04012276 (дата звернення: 08.06.2019).

10. Приватне акціонерне товариство "Завод залізобетонних конструкцій № 1". URL: http://zzbk1.ua/about-company.htm (дата звернення: 08.06.2019).

11. 11TOB «Астроінвест-Енерджі». URL: http://www.astroinvestenergy.com.ua/ (дата звернення: 08.06.2019).

\section{References}

1. Derzhavne publichne aktsionerne tovarystvo «Budivelna kompaniia «Ukrbud» [State Public Joint Stock Company «Construction Company «Ukrbud»], available at: https://smida.gov.ua/db/participant/33298371 (access date June 08, 2019).

2. Richna informaciya emitenta cinnyx paperiv (richnyj zvit) DP $A T \ll B K$ «Ukrbud»za $2018 \mathrm{r}$. [Annual information of the issuer of securities (annual report) of JSC JSC «UkrBud» JSC for 2018], available at: https://kmb.ua/wpcontent/uploads/2019/04/zv\%D1\%96t-kmb-za-2018-r\%D1\%96k.pdf (access date June 08, 2019).

3. UKRBUD rozpoviv pro trendy ta innovaciyi v budivnyctvi na II ForumRED [UKRBUD spoke about trends and innovations in construction at II ForumRED], available at: https://ub.com.ua/news/ukrbud-rozpoviv-pro-trendi-ta-innovatsiji-vbudivnitstvi-na-ii-forumred (access date June 08, 2019).

4. Zvity Kyivmiskbud [Reports of the City of Kyiv], available at: https://kmb.ua/en/about/corporate-information/otchety/ (access date June 08, 2019).

5. Kyyivmis"kbud. Richnyj zvit 2018 [Kyivmiskbud. Annual Report 2018], available at: https://kmb.ua/wp-content/uploads/2019/06/kmb_3105.pdf (access date June 08, 2019).

6. Pryvatne akcionerne tovarystvo «Xoldynhova kompaniya «Kyyivmis"kbud» [Private Joint Stock Company «Kyivmiskbud Holding Company»], available 
at:https://kmb.ua/en/?gclid=Cj0KCQjwov3nBRDFARIsANgsdoHhg_o2vlOpuGCeh wYuwAI0jU_n_3EjyQHIgTupcWklL4wQY1dNBDAaAjpvEALw_wc.201 (access date June 08, 2019).

7. Korporaciya «DBK-ZhYTLOBUD» [Corporation «DBK-ZHITLOBUD»], available at: https://dbkzhytlobud.com.ua/en/ (access date June 08, 2019).

8. Pryvatne akcionerne tovarystvo «Domobudivnyj kombinat № 4» [Private Joint-Stock Company «House-Building Plant №4»], available at: https://smida.gov.ua/db/participant/05503160 (access date June 08, 2019).

9. Pryvatne akcionerne tovarystvo "Zavod zalizobetonnyx konstrukcij №1" [Private Joint-Stock Company «Reinforced Concrete Structures Plant №1»], available at: https://smida.gov.ua/db/participant/04012276 (access date June 08, 2019).

10. Pryvatne akcionerne tovarystvo "Zavod zalizobetonnyx konstrukcij №1" [Private Joint Stock Company «Reinforced Concrete Structures Plant №1»], available at: http://zzbk1.ua/about-company.htm (access date June 08, 2019).

11. TOV «Astroinvest-Enerdzhi» [Astroinvest-Energy LLC], available at: http://www.astroinvest-energy.com.ua/ (access date June 08, 2019).

\section{РЕФЕРАТИ РЕФЕРАТЫ ABSTRACTS}

\section{УДК 69:65.016 ; JEL Classification: D23, L74}

\section{КОНОНова О.Є. РІВЕНЬ ЕФЕКТИВНОСТІ СТРАТЕГІЙ РОЗВИТКУ БУДІВЕЛЬНОЇ ГАЛУЗІ УКРАЇНИ}

Mema: метою дослідження є визначення загального впливу факторів дії, відповідних для будівельної галузі, та впливу додаткових внутрішніх факторів суб' єктів будівельної галузі країни впродовж аналізованого періоду. Методика дослідження: оцінка можлива за умов використання ефективної, грунтовної та надійної методики аналізу. Дана методика оцінки ефективності стратегій розвитку підприємств будівельної галузі України враховує всебічний та широкий діапазон оціночних показників (обсяги доходу (виручки) від реалізації будівельної продукції, обсяги виробництва будівельної продукції, частку ринку згідно планових та звітних параметрів реалізації стратегії розвитку).

У ході виконання дослідження використовувались: - методи системного аналізу і синтезу для розгляду теоретичних аспектів ефективності стратегій розвитку; - методи статистичного аналізу для дослідження фінансового стану будівельних підприємств України; - методи економічного та математичного аналізу для визначення кількісної оцінки та оціночних показників; - методи формальної логіки для розробки висновків та шляхів підвищення ефективності стратегій розвитку будівельних підприємств України. Результати дослідження: у статті проведено розрахунок та оцінку ефективності впровадження планової (задекларованої) стратегії розвитку досліджуваних п'яти підприємств будівельної галузі України за 2015-2017 pp. Наведено порядок оцінки найбільш вагомого впливу факторів на рівень ефективності впровадження стратегій досліджуваних підприємств будівельної галузі країни. Представлена картина стану та трансформацій рівня ефективності впровадження планових (задекларованих) стратегій розвитку досліджуваних 
найбільших підприємств будівельної галузі України впродовж 2015-2017 pp. дозволяє сформулювати основні положення історіографії становлення цієї сфери за вказаний період, серед яких, зокрема: відсутність інвестицій в розвиток, незважаючи на потреби оновлення основних засобів та технологій, що використовуються для впровадження стратегічних параметрів; недостатнє впровадження інновацій в сфері управління методами будівництва, управлінні відходами, управлінні енергоефективністю будівельної продукції та будівництва (встановлено, що тільки два (ДП АТ «БК «Укрбуд» та ПрАТ «ХК «Київміськбуд») з п’яти підприємств використовують інновації і лише одне забезпечує їх ефективне впровадження (a саме, ДП АТ «БК «Укрбуд»)). Проведено оцінку найбільш вагомого впливу факторів на рівень ефективності впровадження стратегій досліджуваних підприємств впродовж 2015-2017 рр. Наукова новизна: вперше обгрунтовано в даному дослідженні визначення загального впливу загальних факторів дії, відповідних для будівельної галузі та впливу додаткових внутрішніх факторів суб'єктів будівельної галузі країни впродовж аналізованого періоду. Встановлено, що на відміну від існуючого підходу, визначається оцінка впливу комплексу зазначених факторів розвитку підприємств будівельної галузі України, які досліджуються через їх позитивну або негативну дію на стан ефективності впровадження планових (задекларованих) стратегій розвитку. Слід відмітити, що всі значення зазначених факторів за окремими вказаними категоріями розраховані в рамках даного дослідження. Доведено, що для визначення найбільш вагомого впливу факторів на рівень ефективності впровадження стратегій досліджуваних підприємств будівельної галузі країни здійснено їх інтегровану оцінку. Практична значущість: представлене дослідження дозволяє оцінити рівень внутрішнього опору впливу зовнішніх, загальних внутрішніх (галузевих) та міжнародних факторів 3 боку найбільших підприємств будівельної галузі України впродовж 2015-2017 рр. Картина стану впливу цих факторів $є$ історіографією стратегічного розвитку суб'єктів галузі протягом вказаного періоду, яка може бути використана для порівняння за параметрами розвитку щодо протидії факторного впливу для інших підприємств в цій сфері (середніх, малих тощо).

Ключові слова: оцінка; методика; розвиток; ефективність; фактори впливу; будівельні підприємства; будівельна галузь.

\section{УДК 69:65.016 ; JEL Classification: D23, L74}

\section{КоНонова А.Е. УРОВЕНЬ ЭФФЕКТИВНОСТИ СТРАТЕГИЙ РАЗВИТИЯ СТРОИТЕЛЬНОЙ ОТРАСЛИ УКРАИНЫ}

Цель: целью исследования является определение воздействия общих факторов действия, определенных для строительной отрасли и влияния дополнительных внутренних факторов субъектов строительной отрасли страны на протяжении анализируемого периода. Методика исследования: оценка возможна при использовании эффективной, основательной и надежной методики анализа. Данная методика оценки эффективности стратегий развития предприятий строительной отрасли Украины учитывает всесторонний и 
широкий диапазон оценочных показателей (объемы дохода (выручки) от реализации строительной продукции, объемы производства строительной продукции, долю рынка согласно плановым и отчетным параметрам реализации стратегии развития). В ходе выполнения исследования использовались: методы системного анализа и синтеза для рассмотрения теоретических аспектов эффективности стратегий развития; - методы статистического анализа для исследования финансового состояния строительных предприятий Украины; - методы экономического и математического анализа для определения количественной оценки и оценочных показателей; - методы формальной логики для разработки выводов и путей повышения эффективности стратегий развития строительных предприятий Украины. Результаты исследования: был проведен расчет и оценка эффективности внедрения плановой (задекларированной) стратегии развития исследуемых пяти предприятий строительной отрасли Украины за 2015-2017 гг. Также был приведен порядок оценки наиболее весомого влияния факторов на уровень эффективности внедрения стратегий исследуемых предприятий строительной отрасли страны.Представленная картина состояния и трансформаций уровня эффективности внедрения плановых (задекларированных) стратегий развития исследуемых крупнейших предприятий строительной отрасли Украины в течение 2015-2017 гг., позволяет сформулировать основные положения историографии становления этой сферы за указанный период, среди которых, в частности: отсутствие инвестиций в развитие, несмотря на потребности обновления основных средств и технологий, используемых для внедрения стратегических параметров; недостаточное внедрение инноваций в сфере управления методами строительства, управлении отходами, управлении энергоэффективностью строительной продукции и строительства (установлено, что только два (ГП АО «СК «Укрбуд» и $3 \mathrm{AO}$ «КК «Киевгорстрой») из пяти предприятий используют инновации, и лишь одно обеспечивает их эффективное внедрение (в частности, ГП АО «СК« Укрбуд»)). Также автором была проведена оценка наиболее весомого влияния факторов на уровень эффективности внедрения стратегий исследуемых предприятий в течение исследуемого периода 2015-2017 гг. Научная новизна: впервые обосновано в данном исследовании определения общего влияния общих факторов действия, характерных для строительной отрасли и влияния дополнительных внутренних факторов субъектов строительной отрасли страны в течение рассматриваемого периода. Установлено, что в отличие от существующего подхода, определяется оценка влияния комплекса указанных факторов развития предприятий строительной отрасли Украины, исследуются через их положительное или негативное воздействие на состояние эффективности внедрения плановых (задекларированных) стратегий развития. Следует отметить, что все значения указанных факторов по отдельным указанным категориям рассчитаны в рамках данного исследования. Доказано, что для определения наиболее весомого влияния факторов на уровень эффективности внедрения стратегий исследуемых предприятий строительной отрасли страны осуществлено их интегрированную 
оценку. Практическая значимость: представленное исследование позволяет оценить уровень внутреннего сопротивления воздействию внешних, общих внутренних (отраслевых) и международных факторов со стороны крупнейших предприятий строительной отрасли Украины в течение 2015-2017 гг. Картина состояния влияния этих факторов является историографией стратегического развития субъектов отрасли в течение указанного периода, которая может быть использована для сравнения по параметрам развития по противодействию факторного влияния для других компаний в этой сфере (средних, малых и т.п.).

Ключевые слова: оценка; методика; развитие; эффективность; факторы влияния; строительные предприятия; строительная отрасль.

\section{UDC 69:65.016 ; JEL Classification: D23, L74 \\ Kononova O. THE LEVEL OF DEVELOPMENT STRATEGIES EFFICIENCY OF UKRAINIAN CONSTRUCTION INDUSTRY}

The purpose: to determine the overall impact of the factors relevant to the construction industry and the impact of additional internal factors of the country's construction industry subjects during the analyzed period. Research Methodology: assessment is possible using an effective, thorough and reliable analysis methodology. Proposed assessing methodology of the effectiveness of strategies development of Ukrainian construction industry enterprises takes into account a comprehensive and wide range of valuation indicators (sales revenue of construction products, volumes of construction products production, market share in accordance with the planned and actual parameters of the development strategy implementation). The following methods were used: - methods of system analysis and synthesis to consider theoretical aspects of the effectiveness of development strategies; - methods of statistical analysis for studying the financial condition of Ukrainian construction enterprises; - methods of economic and mathematical analysis to determine quantitative assessment and evaluation indicators; - formal logic methods for conclusions development and ways to improving the effectiveness of development strategies of Ukrainian construction enterprises. Results: the calculation and evaluation of the effectiveness of the planned (declared) development strategy implementation of the five construction industry enterprises of Ukraine for 20152017 were conducted. The estimation procedure of the most significant influence of factors on the level of implementation effectiveness of strategies of the country's construction industry enterprises was given. The presented results of the state and transformations of the implementation effectiveness level of the planned (declared) development strategies allows to form the basic provisions of the formation historiography of this sphere for the specified period. these include: lack of investment in development, despite the need to upgrade the fixed assets and technologies used to implement strategic parameters; insufficient implementation of innovations of construction methods management, waste management, management of energy efficiency of construction products and construction (it is established that only two (SC JSC "BK "Ukrbud" and PJSC "HK "Kyivmiskbud") are used the innovations and only one enterprise uses effective innovations implementation (SC JSC "BK "Ukrbud"). The most significant influence of factors on the effectiveness 
level of the strategies implementation of the surveyed enterprises during 2015-2017 was estimated. Scientific novelty: for the first time the determination of the overall impact of the general factors of action relevant to the construction industry and the impact of additional internal factors of the subjects of the countrie's construction industry during the analyzed period is substantiated. It is established that, unlike the existing approach, an assessment of the impact of a set of these factors of development of Ukrainian construction enterprises, which are investigated through their positive or negative effect on the state of effectiveness of the implementation of planned (declared) development strategies. It should be noted that all values of these factors for the individual specified categories were calculated within the framework of this study. It is proved that in order to determine the most significant influence of factors on the effectiveness level of strategies implementation of the studied country's construction enterprises, and their integrated assessment was carried out. Practical value: the presented study allows to estimate the level of internal resistance to the influence of external, general internal (sectoral) and international factors by the largest enterprises of the construction industry of Ukraine during 2015-2017. The investigated results of the factors influence state is a historiography of the strategic development of the subjects of the industry during the specified period, which can be used to compare by parameters of development the counteracting of factor influence for other enterprises in this industry (medium, small, etc.).

Key words: estimation; methodology; development; efficiency; factors of influence; construction enterprises; construction industry.

\section{Відомості про авторів / Сведения об авторах / About the Authors}

Кононова Олександра Євгеніївна - кандидат економічних наук, доцент, ДВНЗ «Придніпровська державна академія будівництва та архітектури», доцент кафедри фінансів, обліку та маркетингу, м. Дніпро, Україна; ; e-mail: oleksandrakononova@gmail.com; ORCHID ID: https://orcid.org/0000-0002-72158574. Моб. 097-697-25-55.

Кононова Александра Евгеньевна - кандидат экономических наук, доцент, ГВУЗ «Приднепровская государственная академия строительства и архитектуры», доцент кафедры финансов, учета и маркетинга, г. Днепр, Украина.

Kononova Oleksandra - PhD in Economic Sciences, Associate Professor, Prydniprovska State Academy of Civil Engineering and Architecture, Associate Professor at the Department of Finance, Accounting and Marketing, Dnipro, Ukraine. 